into the newly founded Rhodes-Livingstone Institute with a Secretary-Curator devoting part-time work to developing the museum. By 1945 the work of both the institute and the museum had expanded to such a degree that the trustees decided to separate them, but close contact was and is maintained between the two. In I95 I the museum collections were moved to a new and larger building. The collections are divided into two main series-the exhibited collections and the study and research collections. A reference library, specializing mainly in books on Northern Rhodesia, has been built up and a considerable amount of technological material has been collected. A series of Occasional Papers provides the public with published material on the collections.

The development plan envisages the expansion of both the visual side of the museum work and the research side. The former includes: the development of the schools service, whereby loan cases, film strips, \&c. are borrowed by European and African schools : with the appointment of a full-time Museum Demonstrator or Schools Liaison Officer it is hoped greatly to increase the usefulness of this service; the organization of travelling exhibitions; the establishment of a Natural History Museum in Lusaka or one of the Copperbelt towns; the development of cine photography and general photographic work. In connexion with all these proposals plans have been drawn up for the immediate expansion of existing buildings as well as for gradual and ultimate future expansion. On the research side it is proposed to provide an antiquities service, with a view to stimulating the study of the prehistory and history of the country; to initiate other series of publications, for example, monographs embodying the results of research, handbooks to the museum collections, as well as the publication of the manuscript letters and notebooks of David Livingstone; the expansion of the library by the acquisition of current publications and particularly of old and rare books and manuscripts, and the provision of adequate facilities for music research.

After an outline of the requirements, in staff and equipment, for carrying out the Development Plan, the statement concludes by pointing out that the museum is ' a centre for the preservation of the material elements of the indigenous culture and a focus for the study of the country's past. It depicts for Northern Rhodesians the cultural background of the country in which they live', and it also enables the visitor to learn more of the country's past history and present character.

\title{
Conseil Scientifique pour l'Afrique au Sud du Sahara (C.S.A.)
}

THe third report of the Scientific Council for Africa South of the Sahara, published September 1954, gives a brief review of the history of C.S.A. up to June 1954, and an account of the changes in its organization and staffing which are now being effected. During its first four years (since its formation in 1950) the Council, as chief scientific adviser to C.C.T.A., ${ }^{1}$ has initiated new activities in a number of subjects. But, with the establishment of permanent inter-African Councils and Committees in different subjects, it is to be expected that the main functions of advancing new ideas and plans will pass to them. C.S.A. will perform the important function of keeping the whole system under review, ensuring that overlapping is avoided, and that the various subjects and disciplines receive adequate attention, so that science and technology may fulfil their role in assisting development of the region as a whole. In order to facilitate these aims, it is proposed that the secretariats of C.C.T.A. and C.S.A. shall be amalgamated: London will continue to be the administrative base and Bukavu (Belgian Congo) the scientific base, but both will be under the jurisdiction of one SecretaryGeneral and will have a combined budget.

The Council of C.S.A. met in 1953 at Tananarive; the Executive Council met in January

1 Commission de Coopération Technique en Afrique au Sud du Sahara. 
I954 in London, and three specialist meetings were held: in October 1953 at Nairobi, in November 1953 at Bukavu and in April r954 at Bukavu.

At the eighth Session of C.C.T.A. in 1953 it was decided that an inter-African research fund should be established for the financing of joint scientific projects advanced by C.S.A. or other inter-African bodies and agreed by Member Governments. The first project to be financed from the fund-the preparation of a climatological atlas for Africa-is now in operation.

The report gives a list of activities proposed and carried out under the 20 main heads and Ioo subheads into which the subjects with which C.S.A. is concerned have been classified. Much discussion has taken place on the subject of maps-both large-scale general maps of Africa and special-subject maps. It was agreed that a comprehensive list of all maps available for the region should be maintained and that new editions of C.S.A. publication no. 4, Maps of Africa South of the Sahara, should be published at intervals in two separate parts, one dealing with general and topographical maps and the other with special-subject maps. It was recommended that a small standing committee should be established to ensure co-ordination between map-making authorities.

With reference to Agriculture, notice is given of an inter-African Conference on the mechanization of agriculture, to be held in Uganda in June 1955.

In connexion with Public Health and Medicine many discussions have taken place between C.S.A., C.C.T.A. and the Director of the African Regional Committee of the World Health Organization, with the object of avoiding duplication and building up a system for mutual assistance and exchange of information in all branches of medical science. An inter-African Conference on medical co-operation is to be held at Leopoldville in September 1955 .

Under the heading of Social Sciences considerable activity is reported, including the publication of C.S.A. Publication no. 7, Research in the Social Sciences in Africa South of the Sahara (see Africa, Jan. 1955, p. 93), and conferences on Rural Welfare, on Co-operative Societies and on Education. An inter-African conference on Social Sciences is to be held in September 1955 at Bukavu. As a result of discussions at meetings of C.S.A. and C.C.T.A., an inter-African Committee has been established whose duties will include keeping all aspects of the social sciences and related subjects under continuous review.

In the section of Economic Science it is noted that a survey of the human factors of productivity is to be carried out-in the first place on a national basis in the separate territories, but in such a form that direct comparisons can be made; the co-ordinating point will be the inter-African Labour Institute at Bamako.

C.S.A.'s Directory of Scientific and Technical Libraries (publication no. 3) has been revised and is now issued as publication no. 10. Work is also being done on the prepatation of lists of periodic literature held in the chief scientific and specialized libraries. An innovation in the C.S.A. publications programme has been the issue of news-sheets designed to keep members of the Council and others informed concerning recent developments in the sphere of inter-African scientific and technical co-operation. Four numbers were issued during the year June I953-June I954.

\section{La Presse au Congo}

It paraît actuellement au Congo 70 publications destinées à la population congolaise. Cinq d'entre elles sont patronnées par le Gouvernement. Nous citerons en premier lieu La Voix $d u$ Congolais qui, éditée sous les auspices de l'Administration Coloniale, est entièrement rédigée par des Congolais et jouit d'une large indépendance. La Voix du Congolais est de plus en plus le porte-parole de l'élite congolaise. Publiée mensuellement depuis juillet 1947 c'est dès le $1^{\text {er }}$ janvier I945 que son premier numéro sortit de presse. Son rédacteur en chef est 